\title{
Evaluation of peanut hulls as an alternative to bleaching clays
}

\author{
By M. M. M. Hassanein*, S.M. El- Shami and F.S. Taha \\ Fats and Oils Department, National Research Centre, Dokki, Cairo, Egypt \\ ( ${ }^{*}$ Corresponding author: e-mail: minarmahmoud@yahoo.com)
}

\begin{abstract}
RESUMEN
Evaluación de cáscaras de maní como alternativa a arcillas decolorantes.

Las cáscaras de maní $(\mathrm{PNH})$ fueron carbonizadas a diferentes temperaturas y tiempos, y utilizadas a diferentes concentraciones como una alternativa a las tierras decolorantes. La evaluación de un aceite de soja decolorado con $\mathrm{PNH}$ se ha basado en sus ácidos grasos libres, reducción del índice de peróxidos (PV), reducción de los fosfolípidos (PL), y en la blanqueabilidad. El rendimiento de varias tierras decolorantes de uso comercial fue evaluado y comparado con el de PNH carbonizada. Las mezclas formuladas incluían: PNH y Tonsil-N (TN), PNH y tierras de Fuller (FE) y PNH y O-pasivo (OP). La estabilidad oxidativa de los aceites resultantes fue determinada. Los resultados revelaron que la efectividad de la decoloración con las tierras decolorantes investigadas fue el siguiente: TN $>$ FE $>$ F $>$ TF $>$ OP. La mayor reducción en PV y PL, y la mayor decoloración se logró para el aceite de soja blanqueado con un $2 \%$ de $\mathrm{PHN}$ carbonizada a $500^{\circ} \mathrm{C}$ durante 30 min (PNH"). Las mezclas de PHN" con las tres tierras de blanqueo elegidas indicaron que 1PHN": 2TN dio el mayor porcentaje de decoloración. La miscela de aceite de soja crudo en hexano decolorada usando PNH" resultó mejorar apreciablemente todas las características del aceite, sobre todo la blanqueabilidad. La estabilidad oxidativa fue en el siguiente orden: TN $>$ control $>>\mathrm{FE}>\mathrm{PNH}^{\text {" con valores de }}$ periodo de inducción de 23,1 > 6,43 $>5,73>2,85 \mathrm{~h}$, respectivamente.
\end{abstract}

PALABRAS CLAVE: Aceite de soja - Carbonización Cáscara de maní - Decoloración - Miscela.

\section{SUMMARY}

Evaluation of peanut hulls as an alternative to bleaching clays.

Peanut hulls (PNH) were carbonized at different temperatures, times, and evaluated at different concentrations as an alternative to bleaching clays. Evaluation of bleached crude soybean oil with $\mathrm{PNH}$ was based on their delta free fatty acids, reduction in peroxide value (PV), reduction in phospholipids (PL) and bleachability. The performance of several commercially used bleaching clays was evaluated, for comparison. Mixtures were formulated including: $\mathrm{PNH}$ and Tonsil - $\mathrm{N}(\mathrm{TN}), \mathrm{PNH}$ and Fuller's earth (FE) and $\mathrm{PNH}$ and O-passive (OP) and examined. The oxidative stability of oils was determined. Results for the investigated commercial bleaching clays revealed: TN $>$ FE $>$ F $>$ TF $>$ OP. Highest reduction in PV and $\mathrm{PL}$, and highest bleachability were achieved for soybean oil bleached with $2 \% \mathrm{PNH}$ carbonized at $500^{\circ} \mathrm{C}$ for $30 \mathrm{~min}(\mathrm{PNH}$ "). Mixtures of $\mathrm{PNH}$ " with the three chosen bleaching clays indicated that 1PNH": 2TN gave the highest bleachability. CSO was miscella bleached in hexane using PNH" and resulted in an appreciable improvement in all oil characteristics, especially in bleachability. Oxidative stability of oils was in the following order: TN $>$ control $>\mathrm{FE}>\mathrm{PNH}$ " with Induction period values of $23.1>6.43>5.73>2.85 \mathrm{~h}$, respectively.

KEY-WORDS: Bleaching - Carbonization - Miscella Peanut hull - Soybean oil.

\section{INTRODUCTION}

Bleaching is an essential step in the process of the production of edible vegetable oils. Bleaching is the process of adsorption of mainly coloring matter (pigments) and other minor constituents of the bleaching clays used. During the bleaching of vegetable oils peroxides are degraded and removed, traces of soap and a portion of $\mathrm{Cu}$ and Fe are removed and traces of phospholipids are adsorbed.

The resistance of oil to rancidity is reduced because some of the natural antioxidants such as tocopherols are removed and partial hydrolysis of the oil takes place (Patterson, 1992; Bailey, 1996; Omar et al., 2003)

Naturally, neutral or non activated bleaching clays are derived from clay mineral deposits "Bentonite". The clays used in the edible oil industry range from natural neutral clays to heavily acid activated clays. However, activated carbon is an expensive material.

There is growing interest in using low cost materials for adsorption as an alternative to activated carbons. A suitable adsorbent has to meet the following criteria: it must have a high affinity and high adsorption capacity for the adsorbate; it must result from a safe and economically viable treatment; it must be renewable, if possible.

Chars are the carbonization products from wood, fruit shells, seed hulls, brown coals, lignite, bone char and a range of other natural materials. Seed hulls are attractive low cost materials. Peanut hulls proved to be good adsorbents in the industry. They are good adsorbents for the removal of metals from wastewater (Perissamy and Namassivayam, 1994; Brawn et al., 2000), the removal of cationic dyes from aqueous solutions (Gong et al., 2005), 
and for the uptake of organic compounds from aqueous solutions (Romero et al., 2003).

Peanut hulls showed potential in the oilseed industry. Omar et al. (2003) investigated the use of carbonaceous materials from seed hulls for the bleaching of vegetable oils. Among the seed hulls investigated were cottonseed, peanut, sunflower, soybean, faba bean and lupine hulls. The carbonized hulls proved to be promising when compared to commercially used clays. Lin and Lin (2009) studied the performance of peanut hull ashes in the bleaching of water degummed, and alkali refined soybean oil. Experimental results indicated that the influence of time was not clear, but that $500-700^{\circ} \mathrm{C}$ showed potential as the best calcination temperature for preparing an effective adsorbent.

Economically speaking it would be a great advantage to use carbonized peanut hulls as a partial or a full substitute to the expensive bentonites. The carbonization process is a simple cheap process, while the spent carbonized ash is easily degradable and has little impact on the environment. Thus the aim of the present work was to evaluate carbonized peanut hulls as an alternative to bleaching clays. This goal was carried out by investigating several carbonization temperatures, the time of carbonization and the concentration of peanut hulls. A comparison of the results of bleaching with carbonized peanut hulls and with standard bleaching clays was made. Evaluation of the bleached oils was done on the basis of their free fatty acid content, peroxide value, phospholipid content, bleachability and oxidative stability.

\section{MATERIALS AND METHODS}

\subsection{Materials}

Peanuts were brought from the local market. Peanuts were manually dehulled, and the hulls were washed well with distilled water, dried in an oven at $100^{\circ} \mathrm{C}$ over night, ground in a ball mill and sieved to pass a mesh size screen of $100 \mu \mathrm{m}$.

Freshly extracted CSO was supplied from El-Badrachin Oil Factory, Egypt, on the $6^{\text {th }}$ of October, and dried over anhydrous sodium sulphate.

Fullers earth (FE) a Product of BDH Chemicals Ltd Liverpool, England, Tonsil N (TN) and Tonsil F (TF) are products of (Süd Chemie, A.G., and München Germany). Clays O-passive (OP), and Fulmont (F) products of Wildness, Cheshire, WA\&OJU, England, were supplied by the Cairo for Oil and Soap Company, Cairo, Egypt.

\section{2. Methods}

\subsubsection{Carbonization of peanut hulls}

Dry ground hulls were placed in aluminium crucibles in a muffle furnace that was previously heated to the desired temperature, under a limited supply of air. The investigated temperatures were $300,400,500$, and $700^{\circ} \mathrm{C}$, and the time of carbonization 30,60 , and 120 minutes. The carbonized hulls were cooled and kept in desiccators until use (Gnanasambandam and Proctor, 1997; Omar et al., 2003).

\subsubsection{Bleaching experiments}

A sample $(20 \mathrm{~g})$ of $\mathrm{CSO}$ (FFA $=3.27, \mathrm{PV}=10.85$ and $\mathrm{PL}=51.64)$ was stirred and heated together with $0.4 \mathrm{~g}$ of carbonized peanut hull samples or bleaching earth ( $2 \%$ wt. of oil) in a rotary evaporator (BUCHI Labortechnik AG) at $100^{\circ} \mathrm{C}$ in a hot water bath under reduced pressure for $20 \mathrm{~min}$. The oil was then filtered through a Whatman No. 2 filter paper to remove carbonaceous adsorbent or bleaching earth (Gnanasambandam and Proctor, 1997; Omar et al., 2003).

Bleaching experiments were carried out using the following clays: TN, TF, FE, OP, and F, and the following samples of peanut hulls: Carbonized hulls at different temperatures and time, and peanut hulls carbonized at $500^{\circ} \mathrm{C}$ for $30 \mathrm{~min}$ at different concentrations during the bleaching experiment including: 1.0, 2.0, 2.5, 3.0 and $4.0 \%$.

Bleaching experiments using mixtures of carbonized peanut hulls ( $\mathrm{PNH}$ ) and bleaching clays were carried out according to the following table:

\begin{tabular}{ccc}
\hline Mixture & Ratio & \% in oil \\
\hline PNH : FE & $1: 1$ & 2 \\
PNH : FE & $1: 2$ & 2 \\
PNH : FE & $2: 1$ & 2 \\
PNH : TN & $1: 1$ & 2 \\
PNH : TN & $1: 2$ & 2 \\
PNH : TN & $2: 1$ & 2 \\
PNH : OP & $1: 1$ & 2 \\
PNH : OP & $1: 2$ & 2 \\
PNH : OP & $2: 1$ & 2 \\
\hline
\end{tabular}

Miscella bleaching was carried out as in the above conventional bleaching method but at room temperature ca. $25^{\circ} \mathrm{C}$, with an oil to hexane ratio $1: 1$ $\mathrm{v} / \mathrm{v}$ according to Megahed (2002).

\subsubsection{Analysis}

Free fatty acid (FFA), peroxide value (PV), and phospholipids (PL) were determined according to AOCS (1998). Color index (Cl) was measured following the recommendations of Pons et al. (1960), using a Shimadzu recording spectrophotometer UV - 240. Cl is the sum of 16 readings $(400-550 \mathrm{~nm}) \times 10$. The oxidative stability of the soybean oil samples was determined by the Rancimat method using a 679 Rancimat (Metrohm, Herisav, Switzerland) at $100^{\circ} \mathrm{C}$ with an 
air flow rate of $20 \mathrm{~L} / \mathrm{h}$ according to the method described by Chapman( 1994).

\subsubsection{Calculations}

The percentage of $\triangle F F A=[($ percentage of FFA in crude oil - percentage of FFA of bleached oil) / FFA in crude oil] $\times 100$; per cent reduction in $\mathrm{PV}=[(\mathrm{PV}$ of crude oil $-\mathrm{PV}$ of bleached oil) / PV of crude oil] $\times 100$; per cent reduction in $\mathrm{PL}=$ [(PL of crude oil $-\mathrm{PL}$ of bleached oil)/PL of crude oil $\times 100$; per cent bleachability $=[(\mathrm{Cl}$ of crude oil $-\mathrm{Cl}$ of bleached oil) / Cl of crude oil] $\times 100$.

\subsubsection{Statistical analysis}

The data were analyzed with the analysis of variance (ANOVA) procedure according to Walter and Duncan's (1969) multiple range tests using commercially available software package SPSS Inc. Chicago, IL, $p$ value $<0.05$ was considered significant.

\section{RESULTS AND DISCUSSION}

Peanut hulls, a waste by-product of the oilseed industry, as well as other food industries, is considered a cheap material as well as an environmentally friendly one. Carbon produced from peanut hulls proved to be an efficient adsorbent for cationic dyes, heavy metal ions in waste water treatment, and for the uptake of organic compounds from aqueous solutions (as previously reported in the literature). In a previous work in our laboratory Omar et al. (2003) surveyed several oilseed hulls as adsorbents for bleaching soybean oil. Peanut hulls were one of the surveyed oilseed hulls, examined as carbonized hulls, steam activated hulls, and phosphoric acid activated hulls. Acid activated hulls resulted in having the highest bleachability, followed by carbonized hulls followed by steam activated hulls. Carbonization is the cheapest method of activation. Thus to fulfill our goal a detailed study on the use of carbonized PNH's was designed and executed.

\subsection{Comparison among the different bleaching clays used in the oilseed industry on some oil characteristics and the bleachability of crude soybean oil}

In order to decide the type of adsorbent to be used as a standard for the comparison of the efficiency of $\mathrm{PNH}$ in bleaching crude soybean oil (CSO) the following experiment was carried out:

Soybean oil was bleached using FE, TN and TF, $\mathrm{F}$, and $\mathrm{OP}$ at a $2.0 \%$ concentration and at $100^{\circ} \mathrm{C}$ for $20 \mathrm{~min}$.

Table 1 gives the results of this investigation. The results in the table reveal that TN is the most efficient bleaching earth among the clays investigated. There was a significant difference between soybean oil bleached with TN and all the other soybean oil samples bleached with other clays, regarding per cent reduction in PV, per cent reduction in PL and per cent bleachability. As for the percentage of $\triangle F F A$ there was no significant difference between TN and other clays except for OP which exhibited a significant difference with TN. The highest per cent reduction in $\mathrm{PV}$, for CSO bleached with $\mathrm{TN}$ was $62.69 \%$, compared to $52.0,40.95,40.24$, and $35.56 \%$ PV reduction for oil samples bleached with $\mathrm{TF}, \mathrm{F}, \mathrm{FE}$, and $\mathrm{OP}$, respectively. No significant difference was found in per cent removal of $P L$ between bleaching with TF and FE, but a significant difference between all other treatments was detected. The per cent removal of PL was the highest for TN reaching $70.59 \%$ followed by 47.76 and $47.14 \%$ for FE and TF, followed by 40.46 and $37.44 \%$ for $\mathrm{F}$ and OP. The per cent bleachability for all treated oil samples were as follows: TN $>$ FE $>$ $\mathrm{F}>\mathrm{TF}>\mathrm{OP}$, with values of $48.89>34.87>$ $32.59>31.12>30.12$, respectively.

According to the above results TN and FE were chosen as standards to compare the efficiency of $\mathrm{PNH}$.

Table 1

Effect of different bleaching clays on some oil characteristics and bleachability of crude soybean oil

\begin{tabular}{ccccc}
\hline Sample & $\begin{array}{c}\Delta \text { FFA } \\
(\%)\end{array}$ & $\begin{array}{c}\text { Reduction in PV } \\
(\%)\end{array}$ & $\begin{array}{c}\text { Reduction in PL } \\
(\%)\end{array}$ & $\begin{array}{c}\text { Bleachability } \\
(\%)\end{array}$ \\
\hline FE & $1.93 \pm 0.62^{\mathrm{ab}}$ & $40.24 \pm 1.04^{\mathrm{c}}$ & $47.76 \pm 1.08^{\mathrm{b}}$ & $34.87 \pm 0.50^{\mathrm{b}}$ \\
TN & $1.62 \pm 0.33^{\mathrm{b}}$ & $62.69 \pm 1.83^{\mathrm{a}}$ & $70.59 \pm 0.59^{\mathrm{a}}$ & $48.89 \pm 0.84^{\mathrm{a}}$ \\
TF & $1.84 \pm 0.10^{\mathrm{ab}}$ & $52.00 \pm 2.09^{\mathrm{b}}$ & $47.14 \pm 0.56^{\mathrm{b}}$ & $31.12 \pm 1.61^{\mathrm{bc}}$ \\
F & $1.81 \pm 0.16^{\mathrm{ab}}$ & $40.95 \pm 1.60^{\mathrm{c}}$ & $40.46 \pm 0.44^{\mathrm{d}}$ & $32.59 \pm 2.08^{\mathrm{bc}}$ \\
OP & $2.27 \pm 0.25^{\mathrm{a}}$ & $35.56 \pm 0.48^{\mathrm{d}}$ & $37.44 \pm 0.70^{\mathrm{e}}$ & $30.12 \pm 1.94^{\mathrm{c}}$ \\
\hline
\end{tabular}

FFA $=$ Free Fatty acids, $\mathrm{PV}=$ Peroxide value, $\mathrm{PL}=$ Phospholipids, $\mathrm{PNH}=$ carbonized peanut hulls,

$\mathrm{FE}=$ Fuller's earth, $\mathrm{TN}=$ Tonsil $\mathrm{N}, \mathrm{TF}=$ Tonsil $\mathrm{F}, \mathrm{F}=$ Fulmont, OP=O-Passive.

Means with different letters in the same column are significant; means followed by the same alphabetical letters are not significantly different at $p<0.05$ and means without letters are not significant. SD: calculated from values of four replicates. Crude soybean oil: $\mathrm{FFA}=3.27, \mathrm{PV}=10.85, \mathrm{PL}=51.64$. 


\subsection{The effect of Peanut hulls carbonized at different temperatures and for different periods of time on some oil characteristics and the bleachability of crude soybean oil}

The effect of carbonization time and the temperature of $\mathrm{PNH}$ on the oil characteristics and bleachability of CSO is indicated in Table 2. In these bleaching experiments, all investigated carbonized $\mathrm{PNH}$ and bleaching clays were used at $2 \%$ of the weight of the oil. The results in the table reveal a significant difference in the percentage of $\triangle F F A$ between all the soybean oil samples bleached with $\mathrm{PNH}$ and those bleached with $\mathrm{FE}$, but no significant difference was detected between those bleached with $\mathrm{PNH}$ and those bleached with $\mathrm{TN}$, or among all treatments. It is well accepted that partial hydrolysis of the oil takes place during bleaching and that the extent of hydrolysis depends on the acid properties of the bleaching clays (Patterson, 1992). Our results show no hydrolysis perhaps because of the neutral property of the carbonized hulls. Also the presence of moisture promotes oil hydrolysis during bleaching. In this work this effect is negligible since the CSO was dried over anhydrous sodium sulphate before bleaching. Our results agree with Omar et al. (2003) who reported that carbonized peanut hulls as well as other carbonized oilseed hulls resulted in less hydrolysis of the oil than the steam activated and the acid activated hulls. Proctor and Gnanasambandam (1997), who used carbonized soy hulls to bleach crude soybean oil, reported that the FFA of the bleached oil decreased compared to those of crude oil.

Table 2 also shows the results of the per cent reduction in $\mathrm{PV}$ of the bleached oil over the crude oil as a result of using carbonized $\mathrm{PNH}$. The highest per cent reduction in PV was achieved with TN $>\mathrm{FE}>\mathrm{PNH}-500^{\circ} \mathrm{C}-30 \mathrm{~min}>\mathrm{PNH}-500^{\circ} \mathrm{C}-60 \mathrm{~min}$ $>\mathrm{PNH}-400^{\circ} \mathrm{C}-30 \mathrm{~min}>\mathrm{PNH}-500^{\circ} \mathrm{C}-120$ min with values of $56.69>40.42>36.27>29.13>27.36$ $>25.08 \%$ reduction, respectively. Other $\mathrm{PNH}$ treatments gave bleached soybean oil with values of per cent reduction of PV below $25 \%$. Significant and non-significant differences among treatments can be depicted from Table 2. Bleaching in general causes peroxides to decompose, and one measure of the effectiveness of the bleaching process may be the PV (Bailey, 1996). Our results agree with this statement. Omar et al. (2003) working with oilseed hulls including $\mathrm{PNH}$ reported that all the CSOs bleached with carbonized, steam activated and acid activated hulls resulted in a reduction in the PV of oil, with the highest reduction achieved with acid activated hulls. Ganasambandam and Proctor, (1997); Gananasambandam et al. (1998) reported a reduction in the PV of bleached soybean oil when using carbonized soybean hulls as bleaching agents. De et al. (2009) reported a reduction in the PV of mustard oil when bleaching with rice husk ash and carbonized rice husk silica. Lin and Lin (2009) found that calcinated $\mathrm{PNH}$ at temperatures between $500^{\circ}$ -

Table 2

Effect of carbonized peanut hulls at different temperatures and different Periods of time on some oil characteristics and bleachability of crude soybean oil.

\begin{tabular}{|c|c|c|c|c|c|c|}
\hline & $\begin{array}{l}\text { Time } \\
(\min )\end{array}$ & $\begin{array}{c}\text { Temp. } \\
{ }^{\circ} \mathbf{C}\end{array}$ & $\begin{array}{c}\Delta \text { FFA } \\
(\%)\end{array}$ & $\begin{array}{c}\text { Reduction in PV } \\
(\%)\end{array}$ & $\begin{array}{c}\text { Reduction in PL } \\
(\%)\end{array}$ & $\begin{array}{c}\text { Bleachability } \\
(\%)\end{array}$ \\
\hline \multirow{12}{*}{ 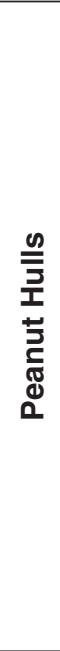 } & 30 & & $1.66 \pm 0.036^{a b}$ & $16.59 \pm 0.40^{f}$ & $26.76 \pm 0.57^{\mathrm{g}}$ & $33.36 \pm 0.29^{d}$ \\
\hline & 60 & 300 & $1.65 \pm 0.036^{a b}$ & $14.54 \pm 0.69^{f g}$ & $23.41 \pm 1.23^{i}$ & $26.65 \pm 0.34^{h}$ \\
\hline & 120 & & $1.72 \pm 0.091^{\mathrm{ab}}$ & $11.50 \pm 0.38^{g h}$ & $21.55 \pm 0.43^{j}$ & $24.21 \pm 0.23^{i j}$ \\
\hline & 30 & & $1.65 \pm 0.16^{\mathrm{ab}}$ & $27.36 \pm 0.72^{c}$ & $32.65 \pm 0.50^{\mathrm{e}}$ & $35.47 \pm 1.08^{c}$ \\
\hline & 60 & 400 & $1.50 \pm 0.26^{\mathrm{ab}}$ & $21.73 \pm 0.72^{\text {de }}$ & $29.79 \pm 0.68^{f}$ & $27.72 \pm 0.96^{\mathrm{g}}$ \\
\hline & 120 & & $1.57 \pm 0.24^{\mathrm{ab}}$ & $18.38 \pm 0.63^{\mathrm{e}}$ & $25.08 \pm 0.95^{h}$ & $24.35 \pm 1.22^{\mathrm{ij}}$ \\
\hline & 30 & & $1.75 \pm 0.19^{\mathrm{ab}}$ & $36.27 \pm 0.87^{b}$ & $40.96 \pm 0.61^{c}$ & $38.32 \pm 0.62^{b}$ \\
\hline & 60 & 500 & $1.63 \pm 0.17^{\mathrm{ab}}$ & $29.13 \pm 0.96^{c}$ & $36.71 \pm 0.42^{d}$ & $31.24 \pm 0.91^{\mathrm{e}}$ \\
\hline & 120 & & $1.65 \pm 0.35^{\mathrm{ab}}$ & $25.08 \pm 1.68^{\mathrm{cd}}$ & $31.60 \pm 0.50^{\mathrm{e}}$ & $29.58 \pm 0.35^{\dagger}$ \\
\hline & 30 & & $1.43 \pm 0.04^{b}$ & $9.19 \pm 0.42^{h}$ & $18.46 \pm 0.51^{k}$ & $30.26 \pm 0.26^{\text {ef }}$ \\
\hline & 60 & 700 & $1.32 \pm 0.04^{b}$ & $6.15 \pm 0.61^{h}$ & $16.00 \pm 1.21^{\prime}$ & $25.11 \pm 0.11^{\prime}$ \\
\hline & 120 & & $1.29 \pm 0.03^{\mathrm{b}}$ & $6.17 \pm 0.98^{h}$ & $10.67 \pm 0.40^{m}$ & $23.62 \pm 0.12^{\mathrm{j}}$ \\
\hline $\mathrm{TN}$ & - & - & $1.66 \pm 0.33^{\mathrm{ab}}$ & $56.69 \pm 8.70^{a}$ & $70.59 \pm 0.59^{a}$ & $48.89 \pm 0.83^{a}$ \\
\hline FE & - & - & $1.93 \pm 0.06^{c}$ & $40.24 \pm 1.04^{b}$ & $47.76 \pm 1.08^{b}$ & $35.13 \pm 0.16^{c}$ \\
\hline
\end{tabular}

$\mathrm{FFA}=$ Free Fatty acids, $\mathrm{PV}=$ Peroxide value, $\mathrm{PL}=$ Phospholipids, $\mathrm{PNH}=$ carbonized peanut hulls, $\mathrm{TN}=$ Tonsil $\mathrm{N}$, $\mathrm{FE}=\mathrm{Fuller}$ 's earth. Means with different letters in the same column are significant; means followed by the same alphabetical letters are not significantly different at $p<0.05$ and means without letters are not significant. SD: calculated from values of four replicates.

Crude soybean oil: FFA $=3.27, \mathrm{PV}=10.85, \mathrm{PL}=51.64$. 
$700^{\circ} \mathrm{C}$ were effective in absorbing peroxides. However $\mathrm{PNH}$ ashes calcinated at 300 and $1000^{\circ} \mathrm{C}$ and untreated $\mathrm{PNH}$ were found not to reduce PV.

Per cent reduction in the $\mathrm{PL}$ of bleached soybean oil can be seen from Table 2. Statistical analyses of the results are clearly indicated in the Table. The highest reduction in PL due to bleaching with different clays and carbonized $\mathrm{PNH}$ was in the following order: $\mathrm{TN}>\mathrm{FE}>\mathrm{PNH}-500^{\circ} \mathrm{C}-30 \mathrm{~min}>$ $\mathrm{PNH}-500^{\circ} \mathrm{C}-60 \mathrm{~min}>\mathrm{PNH}-400^{\circ} \mathrm{C}-30 \mathrm{~min}>\mathrm{PNH}$ $-500^{\circ} \mathrm{C}-120 \mathrm{~min}$ with values of $70.59>47.76>$ $40.96>36.71>32.65>31.60 \%$ reduction, respectively. Other treatments gave lower reductions in PL. It is well accepted that most of the $\mathrm{PL}$ is removed from vegetable oils by degumming prior to refining, yet some of the PL remain in the oil and interferes with the proper deodorization step giving off- graded oils. However the traces of PL still remaining can be removed by adsorption during the bleaching step (Patterson 1992; Bailey 1996). Omar et al. (2003) reported that carbonized PNH can remove PL from bleached soybean oil but to a lesser extent than steam activated, acid activated hulls, TN and FE. Lin and Lin (2009) found that calcinized $\mathrm{PNH}$ ashes are effective adsorbents for the removal of $\mathrm{PL}$, but untreated $\mathrm{PNH}$ was not effective. They also found that the acid activated clays and regenerated clays were superior to $\mathrm{PNH}$ ashes. Proctor and Harris (1996); Gananasambandam and Proctor (1997) reported a general trend in competitive adsorption of the oil species on carbonized soy hulls to be phospholipids $>$ peroxides $>$ free fatty acids. All the previous work reported is in agreement with our results.
Per cent bleachability is taken as an indication of oil color. The best bleachability of the crude soybean oil was achieved when using $\mathrm{TN}>\mathrm{PNH}$ $-500^{\circ} \mathrm{C}-30 \mathrm{~min}>\mathrm{FE}=\mathrm{PNH}-400^{\circ} \mathrm{C}-30 \mathrm{~min}$ at values of $48.89>38.32>35.47=35.12 \%$, respectively. Other bleachability values were $30 \%$ and below for oil samples bleached with carbonized $\mathrm{PNH}$. Significant and non-significant differences among treatments can be drawn from results in Table 2. Contrary to our findings Omar et al. (2003) reported that the bleachability of soybean oil with carbonized PNH was better than the oils bleached with T and FE. While Lin and Lin (2009) reported that calcinated $\mathrm{PNH}$ ashes slightly reduce the lovibond red index. The removal efficiencies are in the range of $0-13 \%$. Untreated $\mathrm{PNH}$ was not effective at all.

According to the above results $\mathrm{PNH}$ carbonized at $500^{\circ} \mathrm{C}$ for $30 \mathrm{~min}$ was the most effective treatment for the removal of the highest values of peroxides and phospholipids in the bleached oils, also resulting in the best bleachability of soybean oil compared to the other treated $\mathrm{PNH}$ and FE. Lin and Lin (2009) recommended $500-700^{\circ} \mathrm{C}$ as most effective calcination temperature and determined that the effect of time of calcination was not clear. Therefore the above treatment was chosen for further investigations.

\subsection{Regression Analysis of Results}

Results of the correlation coefficient study (Table 3) indicate a curvilinear correlation between $\triangle F F A \%$ with time $\left(R^{2}=1\right)$; between $\%$ bleachability with time $\left(R^{2}=1\right)$, except for oil bleached with $\mathrm{PNH}$

Table 3

Correlation between $\Delta$ Free Fatty acid (FFA) \%, Reduction in Peroxide value (PV) \%, Reduction in Phospholipids (PL) \% and \% Bleachability (BL) with carbonization time $(t)$ of peanut hulls at different temperatures.

\begin{tabular}{|c|c|c|c|}
\hline Case & Correlation & $\begin{array}{c}\text { Correlation } \\
\text { Coefficient }\left(\mathbf{R}^{2}\right)\end{array}$ & Range of validity \\
\hline \multirow{4}{*}{$\Delta \mathrm{FFA}$ vs t } & $\Delta F F A=2 E-05 t^{2}-0.0018 t+1.70$ & 1 & from $30-120 \mathrm{~min}$ at $300^{\circ} \mathrm{C}$ \\
\hline & $\Delta F F A=7 E-05 t^{2}-0.0112 t+1.92$ & 1 & from $30-120 \mathrm{~min}$ at $400^{\circ} \mathrm{C}$ \\
\hline & $\Delta F F A=5 E-05 t^{2}-0.0083 t+1.96$ & 1 & from $30-120 \mathrm{~min}$ at $500^{\circ} \mathrm{C}$ \\
\hline & $\Delta F F A=4 E-05 t^{2}-0.0068 t+1.60$ & 1 & from $30-120 \mathrm{~min}$ at $700^{\circ} \mathrm{C}$ \\
\hline \multirow{4}{*}{$\begin{array}{l}\text { Reduction in } \\
\text { PV vs t }\end{array}$} & $\mathrm{PV}=41.385 \mathrm{t}^{0.0287}$ & 0.98 & from $30-120 \mathrm{~min}$ at $300^{\circ} \mathrm{C}$ \\
\hline & $P V=71.853 t^{0.0287}$ & 0.99 & from $30-120 \mathrm{~min}$ at $400^{\circ} \mathrm{C}$ \\
\hline & $P V=88.635 t^{0.0266}$ & 0.98 & from $30-120 \mathrm{~min}$ at $500^{\circ} \mathrm{C}$ \\
\hline & $P V=0.0011 t^{2}-0.203 t+14.263$ & 1 & from $30-120 \mathrm{~min}$ at $700^{\circ} \mathrm{C}$ \\
\hline \multirow{4}{*}{$\begin{array}{l}\text { Reduction in } \\
\text { PL vs t }\end{array}$} & $\mathrm{PL}=45.135 \mathrm{t}^{0.156}$ & 0.98 & from $30-120 \mathrm{~min}$ at $300^{\circ} \mathrm{C}$ \\
\hline & $\mathrm{PL}=47.01 \mathrm{t}^{0.108}$ & 0.99 & from $30-120 \mathrm{~min}$ at $400^{\circ} \mathrm{C}$ \\
\hline & $\mathrm{PL}=77.932 \mathrm{t}^{0.187}$ & 0.98 & from $30-120 \mathrm{~min}$ at $500^{\circ} \mathrm{C}$ \\
\hline & $\mathrm{PL}=74.01 \mathrm{t}^{0.395}$ & 0.93 & from $30-120 \mathrm{~min}$ at $700^{\circ} \mathrm{C}$ \\
\hline \multirow{4}{*}{ BL vs t } & $\mathrm{BL}=0.0017 \mathrm{t}^{2}+0.26 \mathrm{t}+17.063$ & 1 & from $30-120 \mathrm{~min}$ at $300^{\circ} \mathrm{C}$ \\
\hline & $\mathrm{BL}=88.487 \mathrm{t}^{0.274}$ & 0.97 & from $30-120 \mathrm{~min}$ at $400^{\circ} \mathrm{C}$ \\
\hline & $\mathrm{BL}=0.0023 \mathrm{t}^{2}-0.4443 \mathrm{t}+94.56$ & 1 & from $30-120 \mathrm{~min}$ at $500^{\circ} \mathrm{C}$ \\
\hline & $B L=0.0016 t^{2}-0.3185 t+38.347$ & 1 & from $30-120 \mathrm{~min}$ at $700^{\circ} \mathrm{C}$ \\
\hline
\end{tabular}


carbonized at $400^{\circ} \mathrm{C}$ and heated for $30-120 \mathrm{~min}$, which showed a power correlation $\left(R^{2}=0.97\right)$. Bleaching of CSO with $\mathrm{PNH}$ carbonized at $700^{\circ} \mathrm{C}$ for 30 - 120min also exhibited a curvilinear correlation between \% reduction in $\mathrm{PV}$ with time $\left(R^{2}=1\right)$. A power correlation between \% reduction in PV with time $\left(R^{2}=0.98-0.99\right)$ for other treatments was indicated as well as a power correlation between \% reduction in PL with time $\left(R^{2}=0.93-0.999\right)$.

Results from the regression in Table 4 depict the fact that the correlation between the percentage of $\triangle \mathrm{FFA}$, per cent reduction in $\mathrm{PV}$, per cent reduction in $\mathrm{PL}$ and per cent bleachability with temperature was always a curvilinear relationship $\left(R^{2}=0.92-1\right)$, indicating that the increase or decrease in these oil characteristics is not necessarily accompanied by an increase or decrease of time. In the power correlations in this study it is clear that the indicated characteristic (eg PL) decrease with an increase in carbonization time.

\subsection{Effect of concentration of carbonized peanut hull on some oil characteristics and bleachability of crude soybean oil.}

In this experiment the investigated criteria was the concentration of $\mathrm{PNH}$ carbonized at $500^{\circ} \mathrm{C}$ for 30 min. Bleaching was carried out for $30 \mathrm{~min}$ at $100^{\circ} \mathrm{C}$. The concentrations examined were 1.0, 2.0, 2.5, 3.0 and $4.0 \%$ of the weight of the oil. The results from this experiment are presented in Table 5.

It is obvious that the bleaching of crude soybean oil with $2 \% \mathrm{PNH}$ exhibited a significant difference in the percentage of $\triangle F F A$, reduction in $\mathrm{PV}(\%)$, reduction in $\mathrm{PL}(\%)$ and the \% bleachability with oils bleached with other PNH concentrations. The highest values were achieved when using $2.0 \%$ $\mathrm{PNH}$ during bleaching, resulting in oil with $1.68 \%$ $\triangle \mathrm{FA}, 35.88 \%$ reduction in $\mathrm{PV}, 43.97 \%$ reduction in PL, and $38.28 \%$ bleachability of oil. Values for the other treatments are represented in the Table.

Table 4

Correlation between $\Delta$ Free Fatty acid (FFA) \%, Reduction in Peroxide value (PV) \%, Reduction in Phospholipids (PL) \% and \% Bleachability (BL)

with carbonization temperature $(T)$ of peanut hulls at different times $(t)$.

\begin{tabular}{|c|c|c|c|}
\hline Case & Correlation & $\begin{array}{c}\text { Correlation } \\
\text { Coefficient }\left(R^{2}\right)\end{array}$ & Range of validity \\
\hline \multirow{3}{*}{$\Delta$ FFA vs $\mathrm{t}$} & $\Delta F F A=4 E-08 t^{3}+5 E-05 t^{2}-0.0206 t+4.475$ & 1 & from $300-700^{\circ} \mathrm{C}$ at $30 \mathrm{~min}$ \\
\hline & $\Delta F F A=5 E-08 t^{3}+7 E-05 t^{2}-0.0332 t+6.575$ & 1 & from $300-700^{\circ} \mathrm{C}$ at $60 \mathrm{~min}$ \\
\hline & $\Delta F F A=6 E-08 t^{3}+8 E-05 t^{2}-0.0389 t+7.305$ & 1 & from $300-700^{\circ} \mathrm{C}$ at $120 \mathrm{~min}$ \\
\hline \multirow{3}{*}{$\begin{array}{l}\text { Reduction in } \\
\text { PV vs t }\end{array}$} & $P V=0.0005 t^{2}+0.05249 t-93.367$ & 1 & from $300-700^{\circ} \mathrm{C}$ at $30 \mathrm{~min}$ \\
\hline & $P V=0.0004 t^{2}+0.4101 t-71.161$ & 1 & from $300-700^{\circ} \mathrm{C}$ at $60 \mathrm{~min}$ \\
\hline & $P V=0.0004 t^{2}+0.3596 t-63.94$ & 0.95 & from $300-700^{\circ} \mathrm{C}$ at $120 \mathrm{~min}$ \\
\hline \multirow{3}{*}{$\begin{array}{l}\text { Reduction in } \\
\text { PL vs t }\end{array}$} & $P L=0.0004 t^{2}+0.3895 t+54.814$ & 0.92 & from $300-700^{\circ} \mathrm{C}$ at $30 \mathrm{~min}$ \\
\hline & $P L=0.0004 t^{2}+0.3688 t+53.65$ & 0.95 & from $300-700^{\circ} \mathrm{C}$ at $60 \mathrm{~min}$ \\
\hline & $P L=0.0004 t^{2}+0.3402 t+48.126$ & 0.98 & from $300-700^{\circ} \mathrm{C}$ at $120 \mathrm{~min}$ \\
\hline \multirow{3}{*}{ BL vs t } & $\mathrm{BL}=0.0003 \mathrm{t}^{2}+0.3197+44.823$ & 0.98 & from $300-700^{\circ} \mathrm{C}$ at $30 \mathrm{~min}$ \\
\hline & $B L=9 E-07 t^{3}+0.0011 t^{2}-0.4769 t+89.44$ & 1 & from $300-700^{\circ} \mathrm{C}$ at $60 \mathrm{~min}$ \\
\hline & $B L=1 E-06 t^{3}+0.0019 t^{2}-0.821 t+137.05$ & 1 & from $300-700^{\circ} \mathrm{C}$ at $120 \mathrm{~min}$ \\
\hline
\end{tabular}

Table 5

Effect of concentration of peanut hulls on some characteristics and bleachability of crude soybean oil.

\begin{tabular}{ccccc}
\hline $\begin{array}{c}\text { Concentration } \\
\text { of PNH (\%) }\end{array}$ & $\begin{array}{c}\Delta \text { FFA } \\
(\%)\end{array}$ & $\begin{array}{c}\text { Reduction in PV } \\
(\%)\end{array}$ & $\begin{array}{c}\text { Reduction in PL } \\
(\%)\end{array}$ & $\begin{array}{c}\text { Bleachability BL } \\
(\%)\end{array}$ \\
\hline 1 & $0.83 \pm 0.86^{\mathrm{b}}$ & $32.46 \pm 2.15^{\mathrm{b}}$ & $34.07 \pm 1.41^{\mathrm{b}}$ & $34.71 \pm 1.11^{\mathrm{b}}$ \\
2 & $1.68 \pm 0.30^{\mathrm{a}}$ & $35.88 \pm 0.82^{\mathrm{a}}$ & $43.97 \pm 3.66^{\mathrm{a}}$ & $38.28 \pm 0.81^{\mathrm{a}}$ \\
2.5 & $0.80 \pm 0.75^{\mathrm{b}}$ & $31.28 \pm 1.12^{\mathrm{b}}$ & $34.53 \pm 0.51^{\mathrm{b}}$ & $34.91 \pm 0.93^{\mathrm{b}}$ \\
3 & $0.62 \pm 0.04^{\mathrm{b}}$ & $29.48 \pm 0.93^{\mathrm{bc}}$ & $31.81 \pm 0.17^{\mathrm{bc}}$ & $33.72 \pm 0.34^{\mathrm{b}}$ \\
4 & $0.54 \pm 0.40^{\mathrm{b}}$ & $27.01 \pm 1.19^{\mathrm{c}}$ & $29.38 \pm 6.33^{\mathrm{c}}$ & $31.06 \pm 0.44^{\mathrm{c}}$ \\
\hline
\end{tabular}

$\mathrm{FFA}=$ Free Fatty acids, $\mathrm{PV}=$ Peroxide value, $\mathrm{PL}=$ Phospholipids, $\mathrm{PNH}=$ Peanut hulls, $\mathrm{BL}=$ Bleachability. Means with different letters in the same column are significant, means followed by the same alphabetical letters not significantly different at $p<0.05$, and means without letters are not significant. SD: calculated from values of four replicates. Crude soybean oil: $F F A=3.27, P V=10.85, P L=51.64$. 
Thus carbonized $\mathrm{PNH}$ at $500^{\circ} \mathrm{C}$ for $30 \mathrm{~min}$ at $2.0 \%$ concentration of the oil during bleaching was the chosen condition for further work.

\subsection{Effect of mixtures of peanut hulls and clays on some oil characteristics and bleachability of crude soybean oil.}

Results of the previous experiments indicated that $\mathrm{PNH}$ are effective adsorbents in the bleaching of crude soybean oil; they do not cause much hydrolysis of oil; they remove substantial amounts of peroxides and phospholipids and improve oil color. Yet carbonized PNH does not compete with commercially available activated clays commonly used in the oil industry, such as TN and FE. In this experiment mixtures were prepared by mixing $\mathrm{PNH}$ carbonized at $500^{\circ} \mathrm{C}$ for 30 min with TN, FE, and $\mathrm{OP}$ at different ratios and their effects on oil characteristics were examined. Single adsorbent or mixture of adsorbents were added at $2.0 \%$ of wt of oil during bleaching at $100^{\circ} \mathrm{C}$ for 30 min. Results of this experiment are illustrated in Table 6. A statistical analysis of data in Table 6 , clearly indicates the significant and non-significant results among treatments.

Looking at the effect of bleaching CSO with mixtures of PNH and FE on bleached oil color it can be said that the oil bleached with 1PNH:2FE was similar to that bleached with FE alone but was better than oil bleached with $\mathrm{PNH}$ only. Oil color was $\mathrm{FE}>1 \mathrm{PNH}: 2 \mathrm{FE}>\mathrm{PNH}$ with values of 34.87 $>34.70>32.28 \%$ bleachability. Upon examining the mixtures with $\mathrm{PNH}$ : TN resulted in bleached oil colors that were lower than the oil bleached with TN alone but improvement in the oil color took place compared to oils bleached with $\mathrm{PNH}$ alone. The closest color to oil samples bleached with TN (48.92\% bleachability) was 1PNH: 2TN > 1PNH:1TN > 2PNH:1TN, with values $45.41>$ $41.94>39.08 \%$ bleachability. When using mixtures of $\mathrm{PNH}, \mathrm{OP}$ revealed that the oil color of the three mixtures improved compared to the oil bleached with OP alone but was inferior to the oil bleached with $\mathrm{PNH}$.

It can be recommended from these results that in the oil industry the use of carbonized PNH for the bleaching of soybean oil is preferred over the use of OP, producing a considerable saving in costs of production. In the case of the use of FE in the industry it can be substituted by one part carbonized $\mathrm{PNH}$ as in mixture 1PNH:2FE which will also mean some cost reduction in the bleaching process. Another advantage in this work was the use of crude soybean oil thus omitting the refining and degumming steps.

\subsection{Miscella bleaching of crude soybean oil}

Many edible oils from oilseeds have been successfully miscella refined. Miscella refining started originally for cottonseed oil. Justification for miscella refining compared to conventional refining are: a) lower refining loss; b) lighter colored oil resulting from bleaching; c) elimination of the water washing step of the refined oil

Table 6

Effect of mixtures of peanut hulls and bleaching clays on some oil characterstics and bleachability of crude soybean oil.

\begin{tabular}{|c|c|c|c|c|}
\hline Samples and mixtures & $\begin{array}{c}\Delta \text { FFA } \\
(\%)\end{array}$ & $\begin{array}{c}\text { Reduction in PV } \\
(\%)\end{array}$ & $\begin{array}{c}\text { Reduction in PL } \\
(\%)\end{array}$ & $\begin{array}{c}\text { Bleachability } \\
(\%)\end{array}$ \\
\hline Peanut hull (PNH) & $1.75 \pm 0.19^{b c}$ & $35.88 \pm 0.82^{f}$ & $42.30 \pm 1.01^{h}$ & $32.28 \pm 0.81^{f}$ \\
\hline Fuller`s Earth (FE) & $1.93 \pm 0.06^{b}$ & $40.24 \pm 1.05^{\mathrm{de}}$ & $47.76 \pm 1.08^{\mathrm{e}}$ & $34.87 \pm 0.59^{\mathrm{e}}$ \\
\hline Tonsil-N (TN) & $1.61 \pm 3.33^{\mathrm{cd}}$ & $62.69 \pm 1.82^{\mathrm{a}}$ & $70.59 \pm 0.59^{a}$ & $48.92 \pm 0.83^{a}$ \\
\hline O-Passive (OP) & $2.13 \pm 0.15^{\mathrm{a}}$ & $35.56 \pm 0.47^{f}$ & $37.44 \pm 0.70^{j}$ & $29.45 \pm 0.83^{i}$ \\
\hline 1PNH: $1 \mathrm{FE}$ & $1.37 \pm 0.02^{\text {def }}$ & $37.25 \pm 0.63^{f}$ & $44.25 \pm 0.98^{g}$ & $33.18 \pm 1.05^{f}$ \\
\hline 1PNH: 2 FE & $1.32 \pm 0.03^{\text {def }}$ & $39.47 \pm 0.57^{\mathrm{e}}$ & $45.91 \pm 0.32^{f}$ & $34.70 \pm 0.74^{\mathrm{e}}$ \\
\hline 2PNH: 1 FE & $1.45 \pm 0.02^{\text {cdef }}$ & $36.49 \pm 0.45^{f}$ & $43.45 \pm 0.17^{g h}$ & $33.18 \pm 0.43^{f}$ \\
\hline 1PNH: $1 \mathrm{TN}$ & $1.56 \pm 0.02^{\text {cde }}$ & $48.25 \pm 0.58^{c}$ & $57.77 \pm 1.04^{c}$ & $41.94 \pm 0.77^{c}$ \\
\hline 1PNH: 2 TN & $1.52 \pm 0.02^{\text {cde }}$ & $56.16 \pm 2.65^{b}$ & $62.22 \pm 1.41^{b}$ & $45.41 \pm 0.39^{b}$ \\
\hline 2PNH: 1 TN & $1.53 \pm 0.03^{\mathrm{cde}}$ & $41.89 \pm 0.48^{d}$ & $50.84 \pm 0.41^{d}$ & $39.08 \pm 0.26^{d}$ \\
\hline 1PNH: 1 OP & $1.27 \pm 0.01^{\text {ef }}$ & $35.84 \pm 2.78^{f}$ & $39.98 \pm 0.66^{i}$ & $30.86 \pm 0.19^{g h}$ \\
\hline 1PNH: 2 OP & $1.17 \pm 0.01^{f}$ & $35.98 \pm 0.67^{f}$ & $36.84 \pm 0.22^{j}$ & $30.31 \pm 0.83^{h i}$ \\
\hline 2PNH: 1 OP & $1.42 \pm 0.03^{\text {def }}$ & $36.48 \pm 1.21^{f}$ & $38.86 \pm 0.11^{i}$ & $31.60 \pm 0.26^{g h}$ \\
\hline
\end{tabular}

$\mathrm{FFA}=$ Free Fatty acids, $\mathrm{PV}=$ Peroxide value, $\mathrm{PL}=$ Phospholipids, $\mathrm{PNH}=$ Peanut hulls

Means with different letters in the same column are significant, means followed by the same alphabetical letters not significantly different at $p<0.05$, and means without letters are not significant. SD: calculated from values of four replicates.

Crude soybean oil: $F F A=3.27, \mathrm{PV}=10.85, \mathrm{PL}=51.64$. 


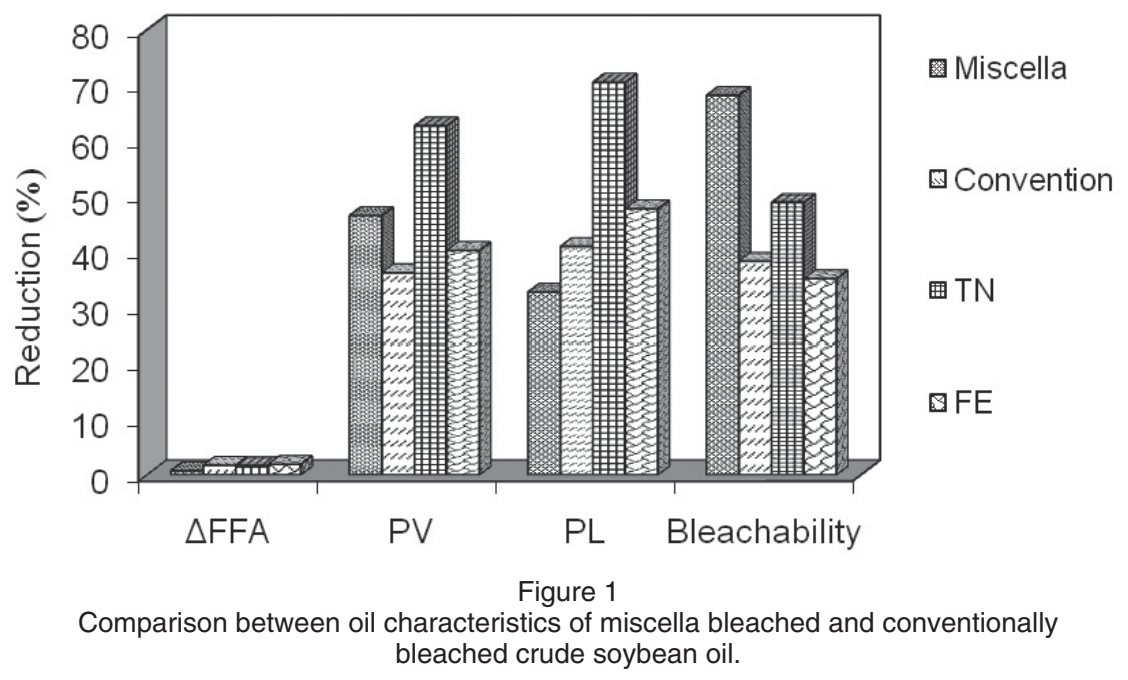

(Cavanaugh, 1976; Megahed, 2002). Little work is reported on miscella bleaching, still it was thought to try miscella bleaching of crude soybean oil with $\mathrm{PNH}$ carbonized at $500^{\circ} \mathrm{C}$ for $30 \mathrm{~min}$ and compare it to conventional bleaching using the same carbonized $\mathrm{PNH}$.

Results of CSO samples bleached with $\mathrm{PNH}$ conventionally and in miscella as well as CSO bleached conventionally with TN and FE are illustrated in figure 1. Comparing miscella bleaching to conventional bleaching using $\mathrm{PNH}$ carbonized at $500^{\circ} \mathrm{C}$ for $30 \mathrm{~min}$, and to TN and FE bleached oils it can be seen that miscella bleaching resulted in bleached oil with superior oil color compared to the other bleached oils. The bleachability of miscella bleached oil is $68.21 \%$ compared to 38.32 , 48.89 , and $35.13 \%$ bleachability for conventionally bleached oil, TN bleached oil, and FE bleached oil, respectively, achieving 46.5, 39.51, and $94.2 \%$ improvement in oil color compared to conventional, TN and FE bleached oils, respectively. The percentage of $\triangle F F A$ was slightly lower for miscella bleaching, while the reduction in PL was lower than the other bleached oils, whereas the reduction in PV for miscella bleached oil was lower than that for TN and FE bleached oils, but higher than conventionally bleached oils. Megahed (2002) carried out an assessment of bleaching cottonseed oil in miscella. In agreement to our results, Megahed (2002) found an insignificant difference in acid value between the two bleaching processes. Miscella bleaching caused a reduction in PV compared to conventional bleaching. Contrary to our results she found that adsorption of coloring matter by miscella bleaching at room temperature was less than that of conventional bleaching at $110^{\circ} \mathrm{C}$. She attributed this to the dark color of cottonseed oil and recommended the use of miscella bleaching for lighter colored oils such as soybean and sunflower. Schmutzler et al. (1994) in their patent of miscella bleaching, bleached cottonseed oil by passing the oil through columns packed with granular bleaching earth with an average particle size of at least $0.5 \mathrm{~mm}$. They recorded that most of the pigments present in cottonseed oil were removed by this process.

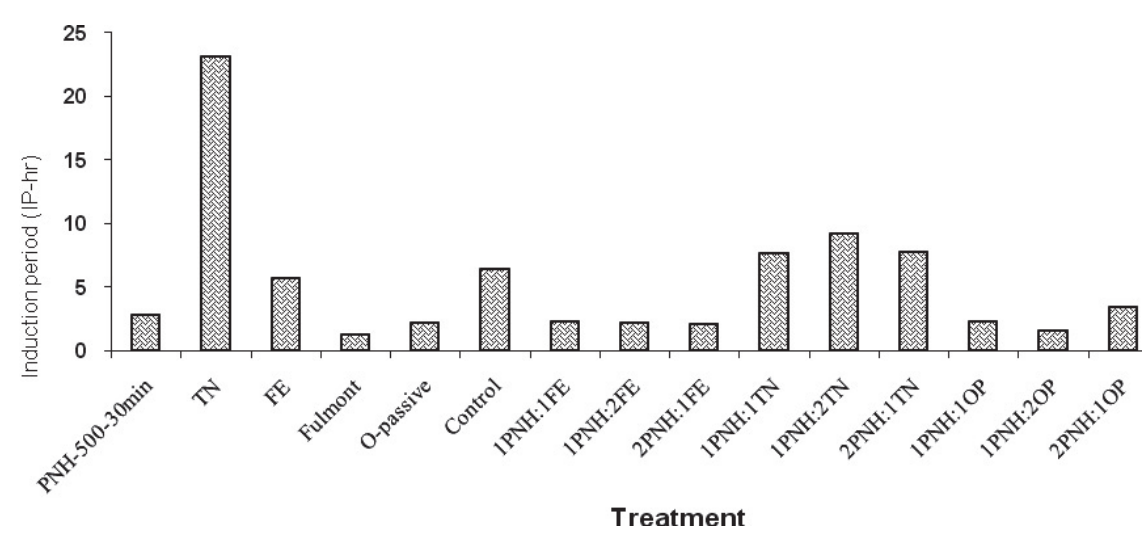

Figure 2

Oxidative stability of soybean oils bleached with $\mathrm{PNH}$, clays and their mixtures, as measured by Rancimat.

$\mathrm{PNH}=$ Peanut hulls, $\mathrm{FE}=$ Fuller's earth, $\mathrm{TN}=$ Tonsil $\mathrm{N}, \mathrm{OP}=\mathrm{O}$-passive 
Miscella bleaching of CSO with carbonized PNH is quite promising but needs further investigation.

\subsection{Oxidative stability of bleached oils}

The oxidative stability of oils and fats is one of the most important parameters for their quality assessment. A number of methods for such assessment have been developed. The Rancimat method measures the induction period (IP) which is the period that precedes the main oxidation process. Figure 2 indicates the IP (hr) for all the examined bleached soybean oils. The IP of the tested oils were in the following order: $\mathrm{TN}>1 \mathrm{PNH}$; $2 \mathrm{TN}>2 \mathrm{PNH}$; $1 \mathrm{TN}>1 \mathrm{PNH}$; $1 \mathrm{TN}>$ control $>\mathrm{FE}$ with values of $23.1>9.31>7.77>7.63>6.43$ $>5.73 \mathrm{hr}$. The other bleached oil samples showed IP values of less than $3 \mathrm{hr}$. These results reveal that the crude soybean oil control with (IP-6.43) is more resistant to oxidation than the oils bleached with $\mathrm{PNH}-500^{\circ} \mathrm{C}-30$ min (IP2.85). Carbonized PNH probably have great affinity to the adsorption of antioxidants such as tocopherols, lecithin, carotenoids and chlorophyll (Hill, 1990) present in the crude soybean oil thus lowering its stability.

\section{CONCLUSION}

The use of carbonized $\mathrm{PNH}$ at $500^{\circ} \mathrm{C}$ for 30 min to bleach CSO is recommended to lower PV, the PL content of oil and to improve its color. Yet $\mathrm{PNH}-500^{\circ} \mathrm{C}-30 \mathrm{~min}$ can be used instead of $\mathrm{FE}$ and OP because their bleaching power is less. On the other hand, $\mathrm{PNH}-500^{\circ} \mathrm{C}-30$ min cannot be used as an alternative to TN, but as a mixture with $\mathrm{TN}$ in ratios that need further investigation. The oxidation stability of crude soybean oil bleached with carbonized PNH is rather low, thus it is recommended to use mixtures of $\mathrm{PNH}$ and TN to improve the oxidation stability. Miscella bleaching of CSO using $\mathrm{PNH} 500^{\circ} \mathrm{C}-30$ min is recommended over conventional bleaching using the same carbonized hull.

\section{REFERENCES}

Bailey S. 1966. In "Industrial Oil and Fat Products". Editor Y.H. Hui, $5^{\text {th }}$ ed., vol.4, pp190-212, NY, John Wiley.

Brawn P, Jefcoat IA, Parrish D, Gill S, Graham E. 2000. Evaluation of the adsorptive capacity of peanut hull pellets for heavy metals in solution. Advances in Environmental Research. 4, 19-29.
Cavanagh GC.1976. Miscella refining. J. Am. Oil Chem. Soc. 53, 361-363.

Chapman DM.1994. Benefits and limitations of a new chlorophyll adsorbent. J. Am. Oil Chem. Soc. 71, 397 $-400$.

De BK, Patel JD, Patel JB, Patel VK, Patel VR.2009. Bleaching of mustard oil with some alternative bleaching agents and acid activated clays. J. of Oleo Science 58, 57-63 .

Ganansambandam R, Proctor A.1997. Soy hull as an adsorbent source in processing soy oil. J. Am. Oil Chem. Soc. 74, 685-692.

Gananasambandam R, Mathias M, Proctor A.1998. Structure and performance of soy hull adsorbents as affected by pyrolysis temperature. J. Am. Oil Chem. Soc. 75, 615-621.

Gong R, Lim M, Yang C, Sun Y, Chen J.2005. Removal of cationic dyes from aqueous solutions by adsorption on peanut hull. J. of Hazardous Materials 121, 247-150.

Hill Steve, 1990. Investigation of Extruded Expelled Soybean Oil. Part of Thesis submitted to University of Illinois at Urbana- Champagne USA.

Lin TL, Lin Cl. 2009. Performance of peanut hull ashes in bleaching water degummed and alkali refined soy oil. Journal of the Taiwan Institute of Chemical Engineers 40, 168-173.

Megahed OA. 2002. Assessment of the process of cottonseed oil bleaching in hexane. Grasa y Aceites 53, 379-383.

Official Methods and Recommended Practices of the AOCS (5 $5^{\text {th }}$ ed.), Champaign, IL. AOCS Press (1998).

Omar S, Girgis B, Taha F.2003. Carbonaceous materials from seed hulls for bleaching of vegetable oils. Food Research International. 36, 11-17.

Patterson HBW.1992. "Bleaching and Purifying Fats and Oils. Theory and Practice". Champaign, IL. AOCS Press.

Perissamy K, Namassivayam C. 1994. Process development for removal and recovery of cadmium from wastewater by a low-cost adsorbent: Adsorption rates and equilibrium studies. Ind. Eng. Chem. Res. 33, 317-320.

Proctor A, Harris CD. 1996. Soy hull carbon as an adsorbent of minor crude oil components. J. Am. Oil Chem. Soc. 73, 527-529.

Pons WAJ, Kuck JC, Frampton VL. 1960. Colour index for cottonseed oils. J. Am. Oil Chem. Soc. 37, 671-673.

Romero LC, Bonomo A, Gonzo EE. 2009. Acid activated carbon from peanut shells: Synthesis, characterization and uptake of organic compounds from aqueous solutions. Adsorption Science and Technology 21, 617-626.

Schmutzler LM, Luis OF, Trujillo- Quijano JA. 1994. Miscella bleaching. European Patent ER 0626444, 18 April.

Walter A, Duncan DB. 1969. Multiple ranges and multiple tests. Biometrics 11, 1-24.

Recibido: 8/11/10 Aceptado: 21/12/10 